\title{
The class basis of the cleavage between the New Left and the radical right
}

\author{
An analysis for Austria, Denmark, \\ Norway and Switzerland
}

\author{
Daniel Oesch
}

\section{Introduction}

The rise of the New Left in the 1980s and the radical right in the 1990s has been widely interpreted as the demise of class politics. Contrary to the established parties, these new movements were seen as no longer relying on particular social groups, but as attracting a broad range of citizens on the basis of their values and attitudes (e.g., Dalton 1996: 332). Taking up the issues of New Politics, these new parties exploit a conflict based on cultural values, which - unlike the material interests drawing the older political divides - were seen to be no longer rooted in different social positions. Likewise, the concept of cleavage-central to the understanding of Old Politics - no longer appeared to make sense with respect to these merely value-based parties.

This chapter fundamentally disagrees with this interpretation and argues that the New Left and the radical right form the opposite poles of a full-grown cleavage in Bartolini and Mair's (1990) sense. This means that their voters combinealongside shared values and a common organization - a structural element, namely a common position within the employment structure. The constituencies of the New Left and the radical right thus not only disagree over issues of identity and community but they also feature very different socio-demographic profiles. This implies that voters' values are no more distributed randomly across the electorate in New Politics than they were in earlier times, but still remain firmly anchored in the social structure.

What has changed is that the rise of the New Left and - a decade later - the radical right triggered a process of electoral realignment where old ties between groups and parties became loose and were replaced by new ties. With respect to the New Left and the radical right, this means that their voters do not only take opposite stances over cultural issues, they also present the mirror image of each other in terms of class and education. The highly educated professionals and semi-professionals in health care, teaching, social welfare and the media disproportionately vote for the New Left, whereas the radical right receives disproportionate support from production workers, artisans and small business owners who rarely hold degrees beyond upper-secondary schooling. 
Exclusively focusing on the demand side of politics, this chapter aims to unearth empirically the class pattern underlying the cultural conflict-and thus to analyze the micro-foundations of the cleavage between the New Left and the radical right. It does so for four small affluent West European countries where the New Left and the radical right have succeeded in the 1990s to establish themselves firmly in the party system: Austria, Denmark, Norway, and Switzerland. Our empirical analysis is based on individual-level data stemming from the first four rounds of the European Social Survey, covering the period between $2002 / 2003$ and $2008 / 2009$. The combination of four survey rounds affords us with large national samples of between 3,000 and 5,000 voters and permits us to go beyond simplistic (and outdated) class measures that just separate the working from the middle class.

Our chapter is structured as follows. Section two examines the critical juncture giving way to the new cultural cleavage and sketches out its underlying class pattern. Section three presents the data and discusses issues related to measuring class position and political preferences. Section four shows the empirical evidence on the ties between social structure and party choice. Section five then adds further results on the link between class position, economic and cultural preferences, and party vote. Section six concludes by putting the principal findings into a wider context.

\section{The class pattern of the cultural cleavage}

In political science and sociology, two misunderstandings about class voting stubbornly linger on. The first misunderstanding consists in reducing class voting to the phenomenon of industrial workers supporting leftist parties. As the link between the working class and labour parties has weakened in some countries (although not in others), some scholars announced the end of class voting (e.g., Franklin et al. 1992; see also Dalton 1996; Clark and Lipset 2001). However, workers' voting for the left is just one instance of class voting; it has - deservedly-received much attention because it overlaps with Europe's central political conflict of the last 120 years, the capital-labour cleavage. Yet several authors correctly pointed out that class voting simply implies the presence of systematic links between voters' class location and the parties they choosewhich classes are linked with which parties is then an empirical question (Müller 1999; see also Evans 2000; Goldthorpe 2000).

A second misunderstanding is to limit the influence of a voter's class position to his or her economic preferences. As opposed to the approach suggested by a narrow Marxist interpretation of class, we argue that an individual's experience at work-insertion into the hierarchy, demand on skills, and interactions with colleagues, clients, and petitioners - contributes to shape his or her attitudes towards material and cultural issues, involving both questions of economy and identity. The idea is that voters generalize from one important sphere of life (work) to another (politics); they thus carry their occupational experiencestheir experience of autonomy and control, of reasoning and routine- over from 
the job to the voting booth (Oesch 2006b: 267; see also Kitschelt 2010: 666; Kitschelt and Rehm 2011a: 6).

It is based on these two preliminary arguments that we expect occupational classes to diverge in their political preferences and party choice. This leads us back to our main argument that the divide between libertarian-universalistic voters of the New Left and traditionalist-communitarian voters of the radical right cannot be reduced to a mere conflict over values, but is also rooted in different positions within the social structure. This raises the question about the critical juncture of this cleavage: what evolution in the market, state or society brought it about? In our view, affluent democracies began to witness in the 1960s and, above all, the 1970s three socio-economic trends that created the potential for a new cultural divide within the electorate: (1) de-industrialization and service sector growth; (2) educational expansion; and (3) occupational upgrading (Kriesi 1999: 400; see also Bornschier 2010a: 63).

The first and possibly decisive change was the onset of de-industrialization in the 1970s, leading to a continuous decline in the proportion of industrial workers relative to the expanding private service personnel. Creation of service jobs was particularly pronounced in the public sector, where the massive expansion of the welfare state - in health care, education and social services - also provided a substantial boost to female labour market participation. Over the same period, the democratization of access to higher education led to a gradual increase in new cohorts' educational attainment. The steady growth among graduates with at least upper-secondary and then increasingly tertiary education was itself influenced by de-industrialization: as demand for semi-skilled industrial labor dried up, young people reacted by staying on at school. Finally, the joint impact of educational growth and service sector expansion, decisively pushed by technological change, led to the gradual upgrading of Western Europe's occupational structure: the share of highly skilled jobs in the professions and management strongly increased at the expense of less qualified jobs in manufacturing, the crafts, and agriculture (Tåhlin 2007; see also Oesch and Rodriguez 2011). Above all in the large European countries, the flip side of the rapid transformation of manufacturing was mass unemployment.

Tertiarization, educational expansion, and occupational upgrading stand for the transition from high industrialism to the service society. This transition has improved the life chances of some categories of the population, while making the prospects more sombre for others. Among the winners are the highly educated employees who took on the growing number of service jobs requiring specialized skills and expertise. This is particularly true for professionals and semiprofessionals in social and cultural services: they benefited both from the opening up of higher education to new social categories (and new professional fields) and from the growth of the public sector (Kriesi 1998; see also Müller 1999). The expanding (semi-)professions in health care, teaching and welfare services proved a particularly effective channel of upward social mobility for women. The transition from an industrial to a service society afforded these occupational groups with relatively comfortable positions within the salaried middle class. 
In contrast, the losers of the transition are primarily concentrated among production workers and small business owners. These mainly masculine categories have lost out from educational growth and occupational upgrading and find themselves at the gradually less populated lower end of the class structure. Subsequent structural changes in the economy-automation of manufacturing, lean production, outsourcing of routine activities - clearly undermined their position in the labor market: the evolution towards a more skill-intensive, rational and competitive service economy worsened their job prospects and reduced demand for their skills (Kitschelt 2007: 1181; see also Kriesi et al. 2008b: 4).

Although rooted in the employment structure, this divide between winners and losers of post-industrialization is not primarily about the economy and the just distribution of resources, but about culture and the definition of identity (Bornschier 2010a). Hence, winners and losers do not chiefly disagree over distributive concerns but over cultural issues: the political regulation of lifestyles (Herbert Kitschelt's grid dimension) and the acceptable extent of cultural diversity (Herbert Kitschelt's group dimension; see Kitschelt 2007: 1179).

Why culture and not economics? Professionals in social and cultural services are wage earners without major managerial responsibilities. As they mostly work in the public sector, they are unlikely to take great concern over the marketliberal interests of capital owners and their delegates, managers. In contrast, they have clearly defined cultural preferences: in their daily face-to-face interaction with patients, students, migrants, or the elderly, they constantly deal with human individuality. Their work process thus mainly consists of social interactionsteaching, nursing, counseling - which are interpersonally negotiated and require tolerance for cultural diversity. These communicative experiences are likely to give forth to a libertarian-universalistic outlook. This outlook is further enhanced by the fact that they mostly work outside clear-cut authority relations and enjoy considerable autonomy - an experience they are likely to generalize to other spheres of life (Kitschelt 1994: 17; see also Kriesi 1999: 169; Müller 1999: 143-144; Kitschelt and Rehm 2011a: 6-7).

The spearheads of libertarian-universalistic values should thus be found among (semi-)professionals engaged in an interpersonal work logic: medical doctors and nurses in health care; social workers and counselors in welfare; professors and teachers in education; journalists and artists in the media and entertainment. These members of the helping, teaching, caring, and entertaining occupations had already dominated the new social movements that crystallized in the 1970s and 1980s. By mobilizing for individual autonomy and the recognition of difference in terms of lifestyle, gender, or sexuality, they had set the foundation for the New Left and notably the Green parties (Kriesi 1989: 1096; see also Bornschier 2010a: 19).

The reaction to the rise of the New Left came with a delay of almost a decade, when radical right populist parties began to surface at the end of the 1980s. In our view, the emergence of the radical right is best understood as the communitarian counter-offensive to the universalistic values promoted by the New Left — as a backlash against post-industrial society and the ideas of 1968 (Ignazi 
1992; see also Minkenberg 2001; Bornschier 2010a). Yet contrary to the offensive claims put on the agenda by the New Left, the radical right found its ideological niche in rearguard action: upholding national demarcation against disappearing borders, defending cultural homogeneity against increasing multiculturalism, salvaging traditional authority against individualistic choice. The contrast is not limited to ideology, but also spans different organizational logics. While the New Left had unfolded in a bottom-up process, where citizen groups mobilized around specific claims that were then adopted by parties, the mobilization of the radical right strongly depended on the deliberate molding of a collective identity by political entrepreneurs - on the presence of the charismatic leader typical of populist parties (Bornschier 2010a: 35-36).

In their rejection of cultural diversity, the radical right encountered the largest resonance among the main groups left out from the transition to the service society: production workers. The radical right's irate resistance to elitist libertarianism and its pointed defense of national traditions received as much support from no other class. The radical right's authoritarian discourse probably proved all the more successful among production workers as their daily job routine of close supervision has been shown to incline them to favor close conformity with rules and to be distrustful of brusque change (Kohn and Schooler 1969: 671). In parallel, rapid educational expansion had boosted the population's libertarian preferences through education's "liberalizing effect" (Kohn and Schooler 1969: 676). This meant that those left out from educational upgrading did not only face decreasing labor demand for their qualifications; they were also likely to find themselves at odds with growing segments of the increasingly well educated and libertarian citizenry, most notably with the elites in politics and the media.

In the end, the radical right's mobilization of production workers could only meet with large success because other collective identities rooted in workingclass culture or religion had become less relevant (Andersen and Bjørklund 1990: 214). As working-class organizations were weakened by deindustrialization and mass unemployment-union membership declining in most affluent countries after 1990 (Bryson et al. 2011: 99) —other collective identities such as belonging to the national community could become salient among workers. In other words, the political potential of the new cultural conflict could only unfold where the established cleavage structure left the space and did not succeed in organizing these new issues (Bornschier 2010a: 4).

In any case, the new identity conflict does not unfold in a political vacuum, but coexists with older distributive and religious cleavages. A production worker may thus be torn between his economic identity as a member of the working class (and vote social democratic), his religious identity as a Catholic churchgoer (and vote Christian democratic), or his cultural identity as a proud member of the national community (and vote for the radical right). Party choice is then determined by the identity that is most salient - and the salience of identities in turn strongly depends on parties' efforts to articulate conflicts and thus to mobilize voters' identities (Bornschier 2010a: 58-59). This context of cross-cutting cleavages also explains why class voting always contains an indeterminate 
element: whether production workers vote for Labour or the radical right, both choices constitute articulate expressions of class-based preferences, where the former choice is based on economic and the latter on cultural preferences.

\section{Strategy of analysis, data and measurement of key concepts}

Our central argument is that the electoral competition between the New Left and the radical right is best understood as a cultural conflict entrenched in different class positions and based on opposing values. The New Left is expected to receive disproportionate support from (semi-)professionals in social and cultural services who hold libertarian-universalistic attitudes, whereas the New Right should primarily draw its strength from the working class - notably production workers - which defends traditionalist-communitarian attitudes. In order to substantiate these claims, our empirical analysis needs to establish the following three elements:

1 the electorates of the New Left and the radical right differ systematically in terms of their class constituencies;

2 these class differences in parties' electorate go along with different cultural preferences;

3 these cultural preferences account to a large extent for the reason why voters from a given class choose either the New Left or the radical right.

These three elements will be analyzed in a comparative perspective. As our focus lies on the demand side of electoral politics - voters' choices - we reduce variation on the supply side of party politics by selecting four small and affluent West European democracies where sizable parties of the New Left and the radical right have established themselves since the 1990s: Austria, Denmark, Norway, and Switzerland. While the New Left in Austria and Switzerland is represented by the Green Party, the major party of the New Left in Denmark and Norway features "Socialist" in its name. Yet both Denmark's Socialist People's Party and Norway's Socialist Left Party are affiliated to the Nordic Green Left Alliance and occupy a similar position in the party space as the Greens in Continental Europe. Table 2.1 gives an overview of the countries' main New Left and radical right parties and averages their electoral share over the national parliamentary elections held between 2000 and 2008. In all four countries, radical right parties obtained somewhat higher electoral scores than the New Left. While the latter's electoral share oscillated everywhere around 10 percent, the radical right obtained between 13 percent (Austria and Denmark), 16 percent (Norway), and almost 30 percent (Switzerland) of the national votes-with sometimes large movements from one election to another, notably in Austria.

Our analysis of class voting is set at the individual level and based on data stemming from the European Social Survey (ESS). By aggregating the four available rounds of the ESS (collected in 2002/2003, 2004/2005, 2006/2007, and 2008/2009), ${ }^{1}$ we obtain large national samples of between 3,000 and 5,000 


\section{The cleavage between New Left and radical right}

voters and thus cover party choice over the last decade. When comparing in Table 2.1 the parties' electoral share in our sample with their effective score, we find radical right voters to be under-represented and New Left voters to be overrepresented in the ESS. Under-representation of Radical Right supporters is a common feature of electoral surveys and has been explained both by these citizens' lower response rates and socially conformist behaviour-people avoid admitting that they have voted for the Radical Right (Ivaldi 2001: 55-56).

In the ESS, respondents are asked what party they voted for in the last parliamentary election. This question provides us with the dependent variable, party choice. Our key independent variable is voters' class position. Drawing on a series of conceptual contributions (Kriesi 1989; see also Erikson and Goldthorpe 1992; Esping-Andersen 1993; Kitschelt 1994), we try to capture the increased heterogeneity in the employment structure by resorting to a detailed class schema based on two dimensions. A first dimension distinguishes hierarchically between more or less advantageous employment relationships based on people's marketable skills. A second dimension discriminates horizontally between four different work logics; it thus distinguishes different occupational experiences of otherwise similarly (dis-)advantaged classes (Oesch 2006b). When combining the two dimensions, we obtain the eight-class schema shown in Table 2.2. In order to convey an idea about the characteristics of different classes, we list for each class a few illustrative occupations and note the share of each class within

Table 2.1 Countries, parties, electoral scores and observations in the ESS

\begin{tabular}{lllll}
\hline & Main party & $\begin{array}{l}\text { Electoral share, } \\
\text { averaged for } \\
\text { National elections } \\
\text { 2001-2008,3 }\end{array}$ & $\begin{array}{l}\text { Electoral } \\
\text { share in ESS } \\
\text { Sample } \\
\text { 2002-2008 }\end{array}$ & $\begin{array}{l}\text { N voters } \\
\text { aggregated in } \\
\text { ESS sample } \\
\text { 2002-2008 }\end{array}$ \\
\hline Austria & NL: Green Party & 10.3 & 16.0 & 5,875 \\
Denmark & RR: FPÖ (+BZÖ) & 12.6 & 6.9 & \\
Norway & NL: SF (+EL) & 10.3 & 12.0 & 5,685 \\
& RR: DF & 13.2 & 8.5 & \\
Switzerland & NL: SV (+RV) & 11.9 & 13.8 & 6,472 \\
& RR: FrP & 18.4 & 16.2 & \\
& NL: Green Party & 8.5 & 10.7 & 6,390 \\
\hline
\end{tabular}

Notes

$1 \mathrm{NL}=$ New Left, $\mathrm{RR}=$ radical right.

2 Data for Austria are only available for the three first rounds (ESS02-ESS06). Accordingly, the effective electoral share has been calculated on the basis of the parliamentary elections 2002 and 2006 only (without 2008).

3 Source: own calculations based on European Election Database (http://eed.nsd.uib.no).

Abbreviations

Austria-FPÖ: Austrian Freedom Party; BZÖ: Alliance for the Future of Austria.

Denmark—SF: Socialist People's Party; EL: Red-Green Alliance.

Norway—SV: Socialist Left Party; RV: Red Electoral Alliance; FrP: Progress Party.

Switzerland-SVP: Swiss People's Party. 


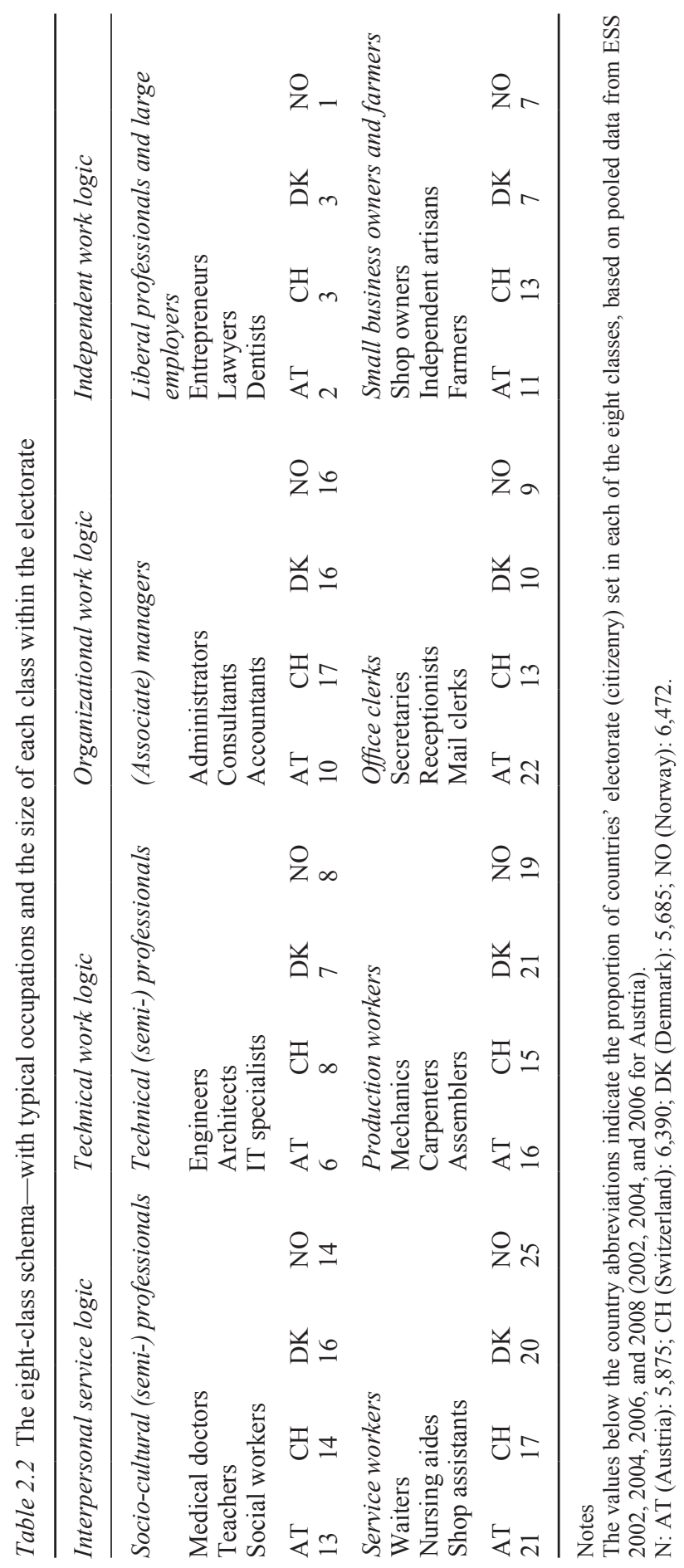


the four countries' electorate in the 2000s, restricting our sample to national citizens.

Class location is measured on the basis of the respondents' current or past employment. If respondents do not mention any occupation, their class location is derived from their partner's present or past employment. Once we have determined the relevant source of their employment, respondents are then allocated to classes based (1) on their employment status, separating employers and the selfemployed from the much larger category of employees, and (2) on their (past or present) occupation, as measured by the over 400 occupational codes in the ESS (ISCO-88 at 4-digit). The process followed to allocate occupations to different classes is described in more detail elsewhere (Oesch 2006b: 270-272).

Alongside the class variable, we construct two composite indices to capture citizens' preferences on an economic-distributive and a cultural-identitarian axis. For each of the two axes, we select four questions that seem, from a theoretical point of view, well suited to translate the underlying attitudes towards economic redistribution and cultural diversity. We then run first a factor analysis on economic attitudes by using the following four items (factor loadings decreasing in this order): (1) standard of living for the unemployed is government's responsibility; (2) Standard of living for the old is government's responsibility; (3) a job for everyone is government's responsibility; (4) government should reduce differences in income levels. This index gives us a measure for an economic axis going from a socialist to a capitalist pole.

We then run a second factor analysis on cultural attitudes by using another four items (factor loadings again decreasing in this order): (1) a country's cultural life is undermined or enriched by immigrants; (2) immigrants make a country a worse or better place to live in; (3) gays and lesbians should be free to live as they wish; (4) European unification has gone too far or should go further. This measure gives us a proxy for the cultural dimension underlying the politics of identity and community, which stretches from a libertarian-universalistic to an authoritarian-communitarian pole. By combining the attitudes on the two axes, we are able to determine voters' position in a two-dimensional political space as sketched out, among others, by Herbert Kitschelt (Kitschelt 1994: 27). The factor loadings of these two composite indices countries are shown in Tables A2.1 and A2.2 in the Appendix. Note that in both cases, one single factor explains over 90 percent of the variance in the items. ${ }^{2}$

\section{Results for class voting}

Our analysis starts with a look at the class basis of the New Left and the radical right in the four countries under study. Figure 2.1 presents the proportion in each class voting for either the New Left or the radical right, where horizontal bars to the left imply less-than-average support and bars to the right more-than-average support (blank bars mean not significantly different from the average). Only one class stands out as lending disproportionate support to the New Left: sociocultural (semi-)professionals. Would the electorate entirely consist of this new 
and still growing class, the New Left would obtain between 22 percent and 33 percent of all votes in the four countries under study - at least twice its effective electoral score. In contrast, production workers are very unlikely to support the New Left: among production workers, the New Left receives one out ten votes at best (Denmark), and one out of twenty-five votes at worst (Switzerland). In Denmark, Norway, and Switzerland, production workers are joined by small business owners and clerks, who also manifest very little sympathy for the New Left.

When turning to the radical right, we find production workers to be its strongest supporters in all four countries: 30 percent among them vote for Norway's Progress Party and even 40 percent for the Swiss People's Party. In Denmark, Norway, and Switzerland, the radical right is also particularly successful in obtaining the support of service workers - the newer and more feminine component of the working classes. On the contrary, the radical right does not hold much appeal for socio-cultural (semi-)professionals. Were it only for this class, the radical right parties under study would be condemned to an insignificant minority status. Quite generally, the radical right receives lower-than-average support from the (upper)-middle classes, be they salaried (socio-cultural and technical professionals as well as managers) or self-employed (liberal professionals and large employers).

In sum, Figure 2.1 shows the class constituencies of the New Left and the radical right to present the almost exact mirror image of each other. Moreover, there is a striking similarity in the class pattern across countries: despite differences in their institutions, party systems, and political culture, we find in all four countries the same classes to rally behind the radical right and avoid the New Left (production workers and small business owners), as to support the New Left and to shun the radical right (socio-cultural professionals).

That these differences in electoral shares are not irrelevant becomes clear when we adopt a compositional perspective and disaggregate each camp's electorate according to class. Figure 2.2 shows that the New Left depends much more than the radical right on the votes of professionals: in all four countries, socio-cultural, technical, and liberal (semi-)professionals represent at least 40 percent of the New Left's voters, but 18 percent at most of those of the radical right. In contrast, clerks, production, and service workers - three categories without secure middle-class status - make up two-thirds of the radical right's electorate as compared to only 40 percent of the New Left in Austria, Denmark, and Norway. In Switzerland, the electoral relevance of the working classes is much smaller than in the other three countries because of a disproportionate share of - disenfranchised-immigrant workers. Yet the differences in the party constituencies are no less striking: the Swiss People's Party receives 44 percent of its votes from production workers, service workers, and clerks, as compared to only 18 percent from (semi-)professionals. The opposite is true for the New Left: 51 percent of its electorate are (semi-)professionals, but only 17 percent are production workers, service workers, and clerks. The New Left thus relies in all four countries on the middle classes, whereas the radical right is clearly dominated by the working classes. 

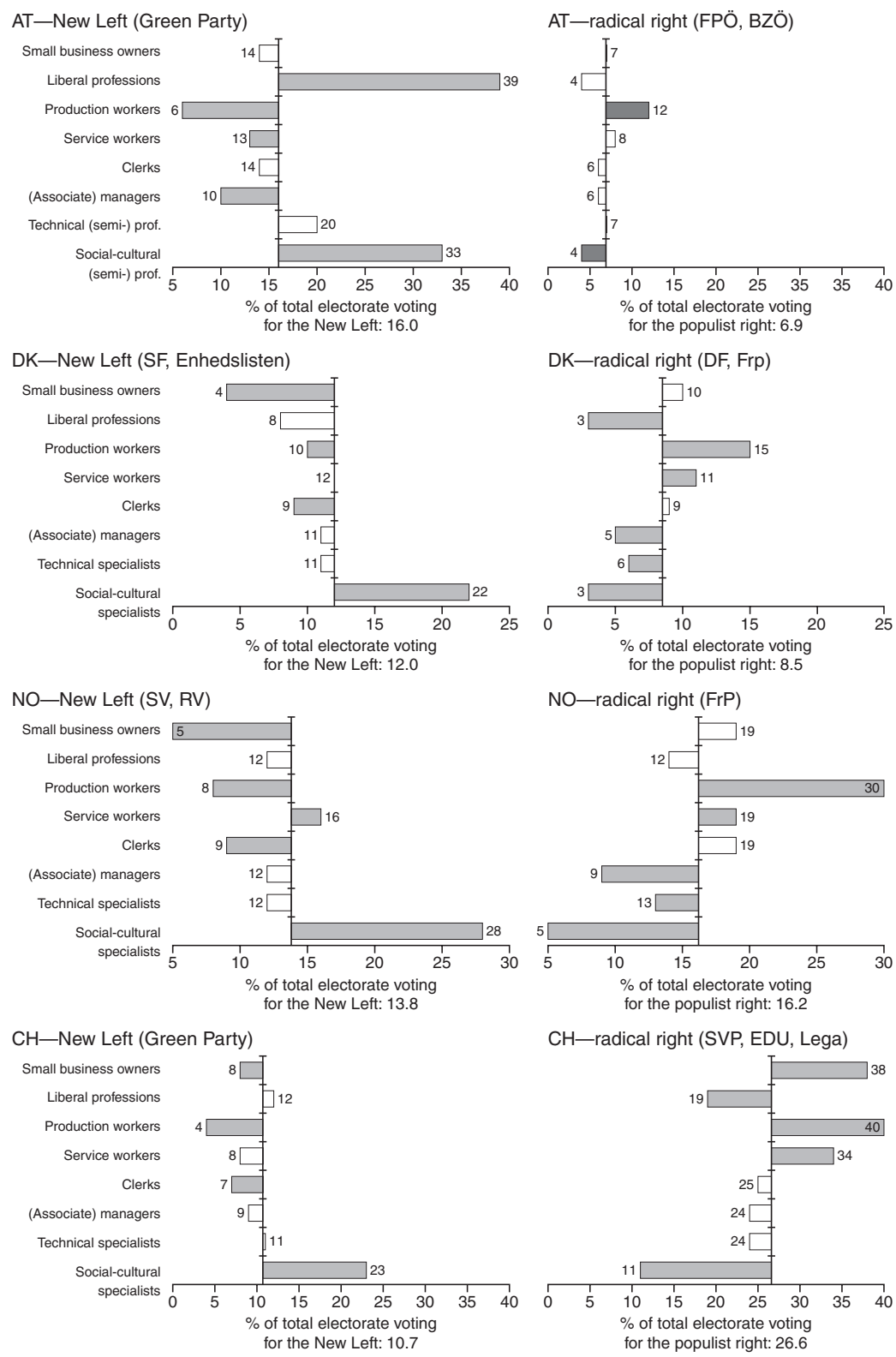

Figure 2.1 The electoral score of the New Left and the radical right by class in the 2000 s.

Notes

Blank columns signify that the electoral scores of these classes are not statistically different from the party's total score in the electorate. Statistical significance is based on t-tests and $p<0.05$.

N: Austria: 3,458; Denmark: 4,848; Norway: 5,074; Switzerland: 3,202. 


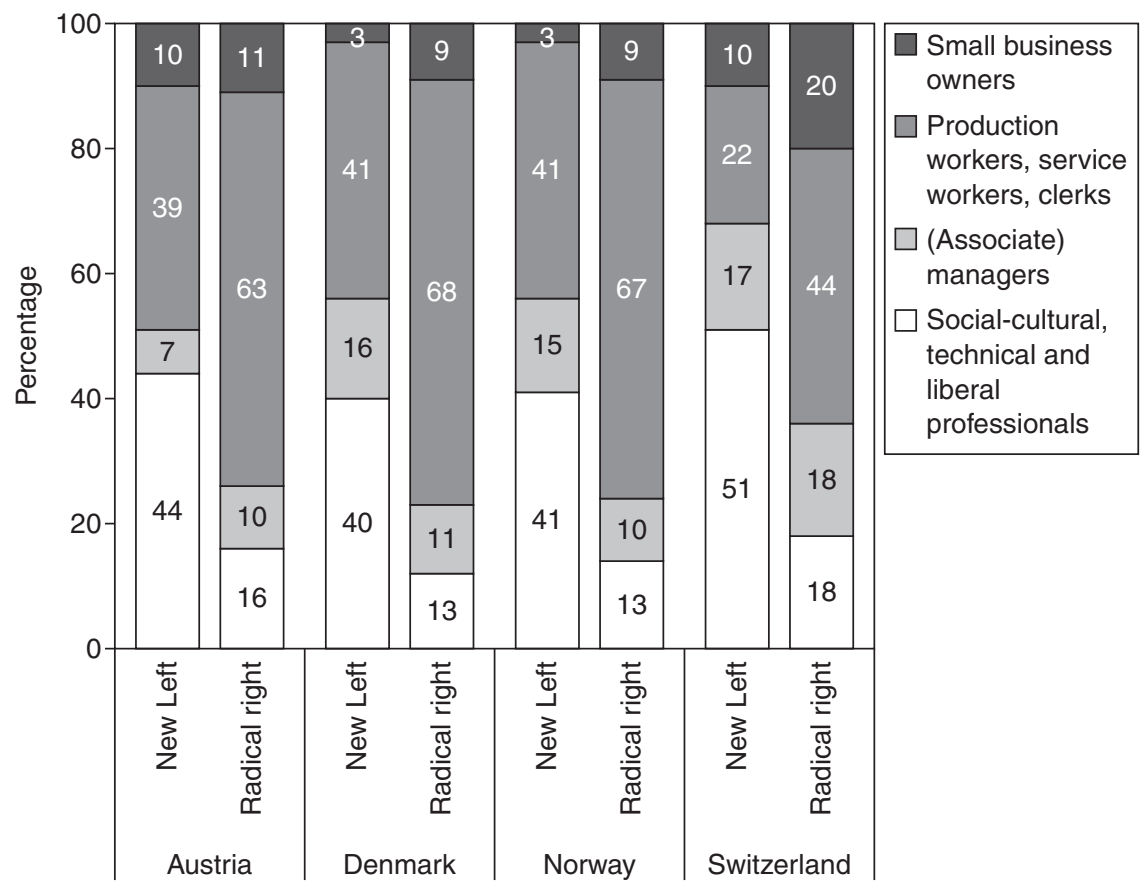

Figure 2.2 The class composition of the electorate of the New Left and the radical right.

An open question is whether the relationship between particular classes and political parties still holds once we take into account other individual characteristics such as gender, age or education. The electorates of the New Left and the radical right diverge much more in terms of gender than do those of the old left and the center right. In all four countries, the New Left attracts significantly more support from women than men, whereas the radical right is everywhere more successful among men than women. The gaps are particularly marked for Norway's Socialist Left Party at the one extreme (obtaining 10 percent of male and 18 percent of female votes) and the Austrian Freedom Party at the other (9 percent of male and 5 percent of female votes); but gender differences are by no means limited to these two parties - quite to the contrary, the parallels between countries are again remarkable. ${ }^{3}$

The two party families also diverge with respect to age. The New Left presents everywhere the youngest electorate, whereas the radical right has, on average, the oldest voters in Austria and Denmark and the second oldest in Norway and Switzerland. However, more relevant for the understanding of the new cultural conflict than age is education. Figure 2.3 shows that the relationships between educational attainment and party choice go into opposite directions for the New Left and the radical right. While support for the New Left rises steeply with increasing education, endorsement of the radical right drops with 

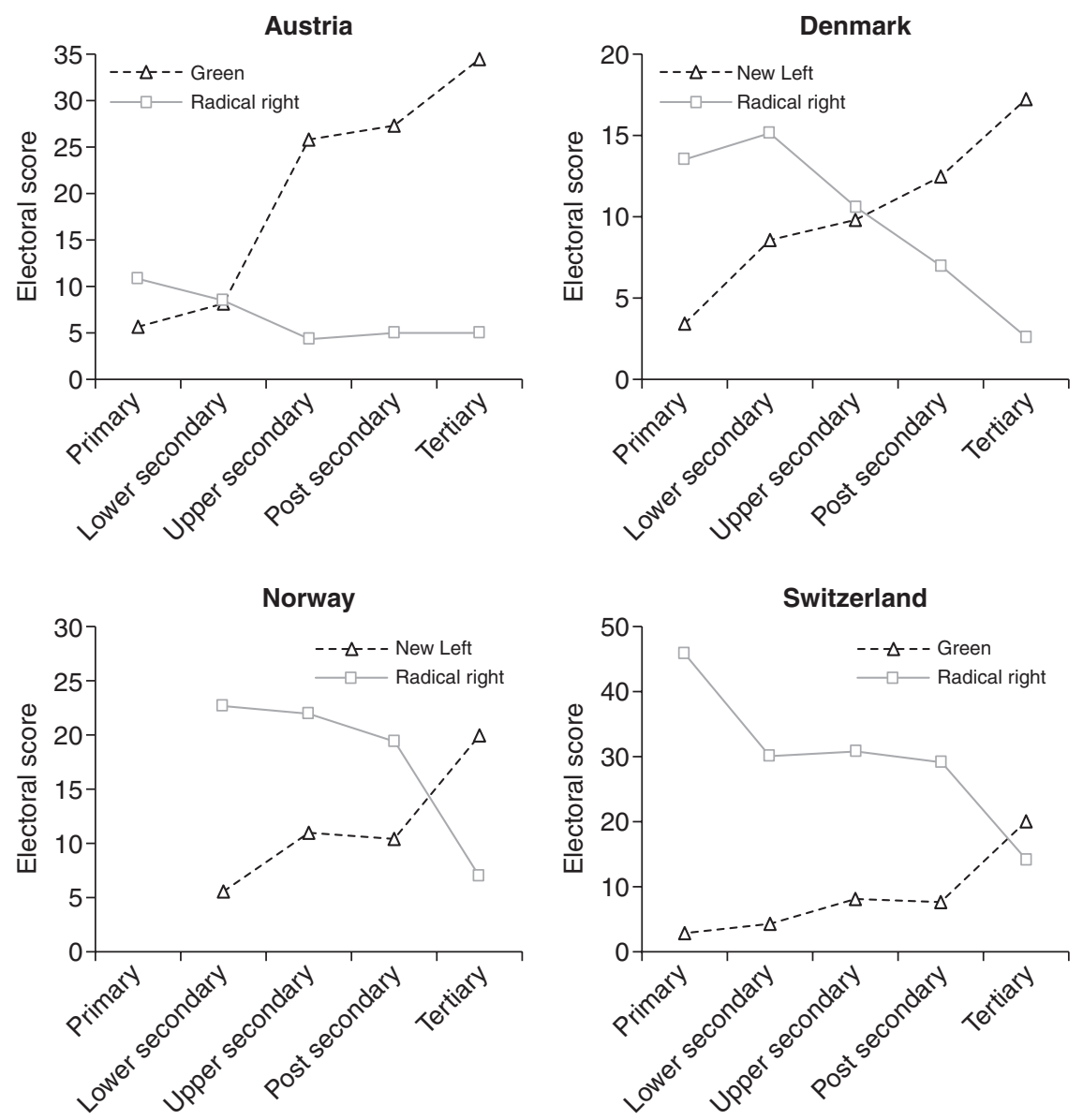

Figure 2.3 The electoral score of the New Left and the radical right by educational level in the 2000s.

Notes

N: Austria: 2,381; Denmark: 4,960; Norway: 5,226; Switzerland: 3,320.

rising education. As a result, citizens with no more than lower-secondary schooling are more likely to vote for the radical right than the New Left in all four countries, whereas holders of tertiary degrees give everywhere stronger support to the New Left than the radical right. These different propensities to vote for either party are also reflected in the composition of the respective electorates. In Denmark, Norway, and Switzerland, over 40 percent of the New Left's voters went to university or technical college as compared to less than 16 percent among radical right voters.

What happens to class once we control for differences in gender, age, and education? The results of multinomial regressions on party choice suggest that in 
all four countries, the class effect on party choice becomes weaker once we account for years of education (and the somewhat less consequential variables of gender and age). Yet in all four countries socio-cultural professionals remain nonetheless significantly more likely to vote for the New Left-as do production workers, together with service workers in Austria, Denmark, and Norway, to vote for the radical right than the reference category of (associate) managers. ${ }^{4}$ Hence, although every additional year of education tips the balance away from the radical right toward the New Left, voters' class position continues to play a central role. Managers and socio-cultural professionals may have similar levels of education; their diverse occupational experiences still set them apart in terms of economic and cultural preferences. In any case, the temptation to play off class against education is somewhat academic as the two concepts are closely linked: access to several classes such as the socio-cultural and technical professions depends upon the successful completion of higher education: being a medical doctor, a lecturer or an engineer presupposes the existence of a tertiary degree. In contrast, class positions in routine production or service work make the possession of advanced education unlikely, as it is neither requested nor put to effective use in the job.

We try to make the results from multinomial regression accessible by calculating the predicted probabilities to support either the New Left or the radical right for the average voter: a man aged forty-five years, who either works as a socio-cultural professional or a production worker. Figure 2.4 shows that even when age and gender are held constant, the two classes strongly diverge in their

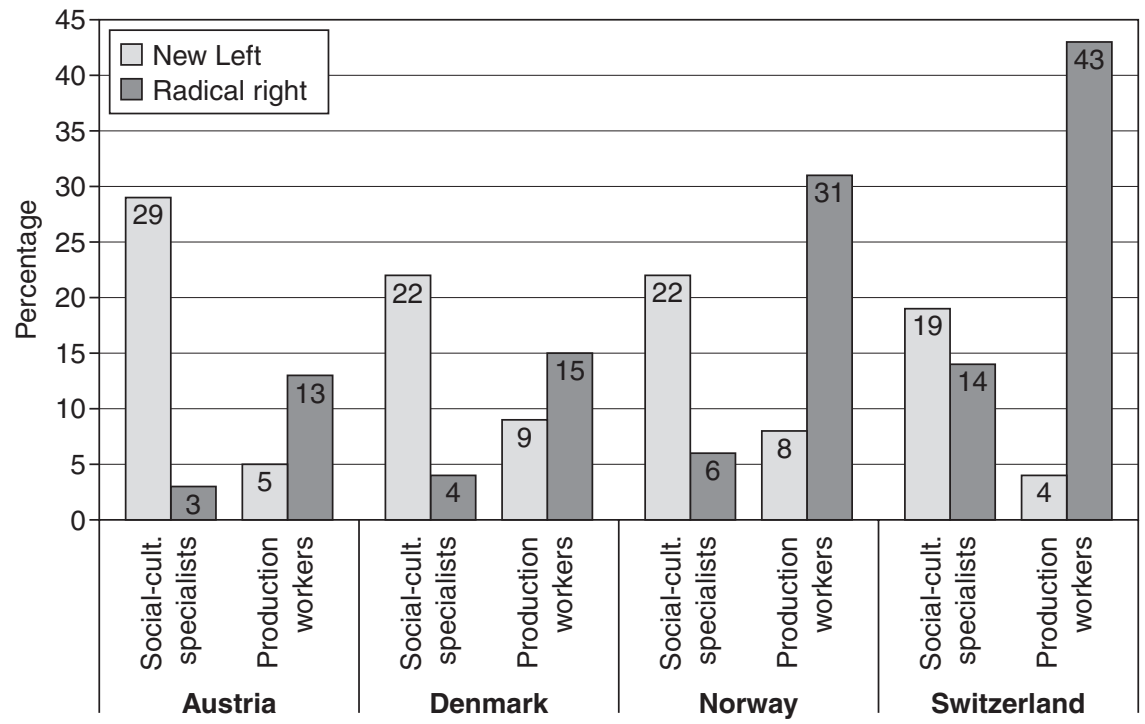

Figure 2.4 Predicted electoral share for the New Left and the radical right among fortyfive-year-old men, working either as socio-cultural professionals or production workers (in \%). 
party choice. Among middle-aged male socio-cultural professionals, between 19 percent (Switzerland) and 29 percent (Austria) vote for the New Left, but only between 3 percent (Austria) and 14 percent (Switzerland) for the radical right. In contrast, middle-aged men employed as production workers are much less likely to support the New Left than the radical right. Differences are largest in Norway and Switzerland, where only 8 percent and 4 percent respectively vote for the New Left, but 31 percent and 43 percent vote for the radical right. The large differences between these two classes are not trivial, as socio-cultural professionals account for about 15 percent (tendency rising) and production workers for about 20 percent (tendency falling) of the electorate.

\section{The cultural and economic preferences linking classes and parties}

So far, our analysis has been limited to structural determinants of voting for the New Left or the radical right. However, the concept of cleavage implies the existence of a shared normative element - a common set of values - which provides a sense of identity to citizens' socio-structural position and thus converts it into voting (Bartolini and Mair 1990: 199). In other words, values and attitudes should pick up the class effect and translate it into party choice. Accordingly, we integrate voters' economic and cultural preferences into our analysis of the link between class location and party choice. We do so by constructing a twodimensional political space, as sketched out, among others, by Kitschelt (Kitschelt 1994: 27; see also Kriesi et al. 2008b: 13). The horizontal axis distinguishes voters' attitudes towards the economy, going from a redistributive socialist pole to a free-market capitalist pole. The vertical axis separates voters according to their attitudes towards the political regulation of lifestyles and cultural diversity, going from a libertarian-universalistic to an authoritariancommunitarian pole.

Based on the factor analyses discussed above, we plot voters' preferences on the economic and cultural axes into the two-dimensional political space shown in Figure 2.5. While we calculate voters' mean preferences at the level of both occupational classes and party families, it is important to note that our analysis only carries on the electoral demand side: we depict parties' positions on the basis of their mean voter's economic and cultural preferences, and not on the basis of parties' programmes or stances over specific issues. Three findings in Figure 2.5 are noteworthy.

First, at the party level, we find voters of the radical right to occupy in all four countries the authoritarian-communitarian extreme of the cultural preference axis. While they differ very little from center-right voters in terms of economic preferences, sharing the same (Austria and Denmark) or almost the same (Norway and Switzerland) position on the state-market axis, they take a markedly more authoritarian stance over cultural issues. In consequence, they are at greatest variance with the New Left's electorate, which clusters at the libertarian-universalistic end of the cultural preference axis. While voters of the New Left are as strongly in favor of 


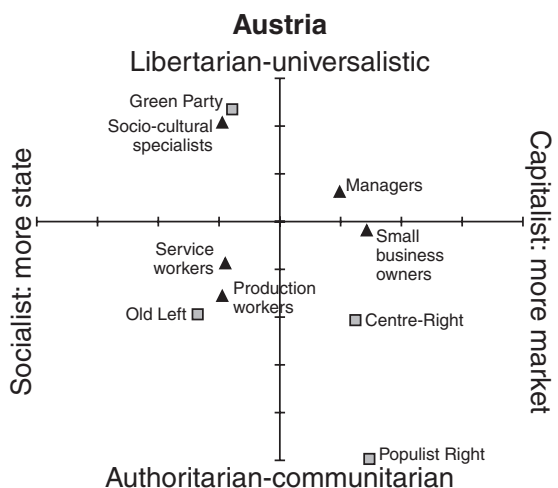

Norway

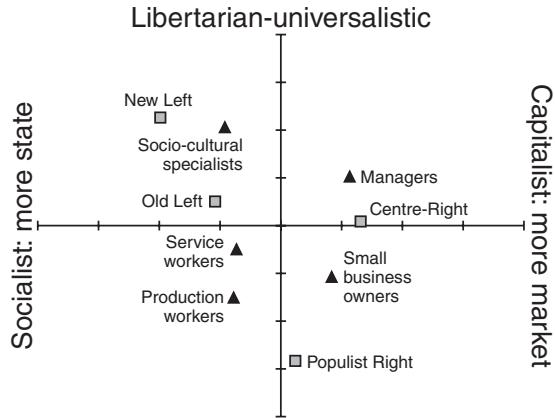

Authoritarian-communitarian

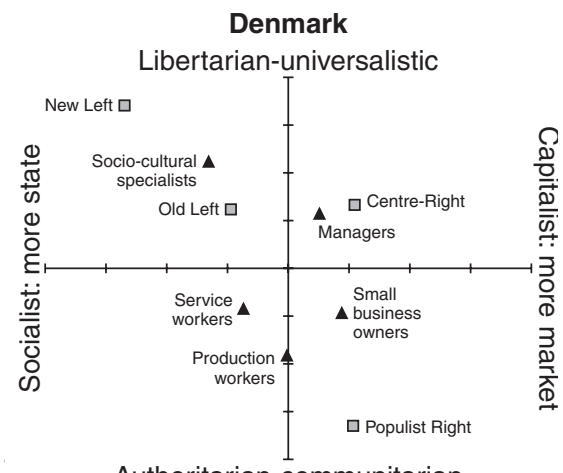

Authoritarian-communitarian

Switzerland

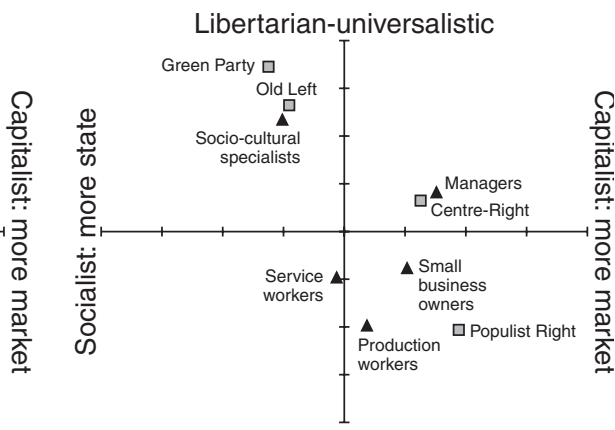

Authoritarian-communitarian

$\Delta$ Classes $\square$ Parties

Figure 2.5 Voters' mean position on the economic (state-market) and cultural (integration-demarcation) preference axis, aggregated by class and party choice.

Note

See Tables A2.1 and A2.2 in the Appendix for the questions used to construct the factors underlying the two axes. Three relatively small classes have not been included into the graphs: clerks, technical specialists, and liberal professionals/large employers.

economic redistribution as the old left's electorate, they occupy culturally a much more libertarian position everywhere, except in Switzerland where the Social Democratic Party also adopted the claims of the new social movements. In the other three countries, the electorates of the two dominant party families, the old left and the center right, only disagree over economic issues, but share a similarly centrist position on cultural issues related to immigration, homosexuality, and European integration. This suggests that the two old party families mainly oppose each other over an economic conflict ('Old politics'), whereas the two new party families collide over a cultural divide ('New Politics').

Second, at the class level, socio-cultural professionals stand out as being particularly libertarian. In all four countries, they occupy the libertarian-universalistic end 


\section{The cleavage between New Left and radical right}

of the cultural axis, and are thus a good distance away from the other large category of the salaried middle class: (associate) managers. While socio-cultural professionals also take a more leftist stance over economic issues, what sets them apart is their cultural libertarianism. The opposite - authoritarian-end of the cultural axis is occupied by small business owners, service workers, and, above all, production workers. No other class has preferences so traditionalistcommunitarian as production workers in our four countries. Interestingly, production and service workers are close to the old left in terms of economic attitudes. What moves them into the vicinity of the radical right are their cultural preferences. The radical right thus seems to secure the support of large workingclass segments not thanks to its market-liberal program, but despite it (Ivarsflaten 2005; see also Oesch 2008). Depending on whether economic or cultural issues are more salient, production and service workers are likely to vote either for the old left or the radical right.

Third, it is remarkable how much alike the political space looks in the four countries under study. Even though we run a separate factor analysis for each country, we obtain striking cross-country similarities in both economic and cultural preferences of party families and occupational classes. We find it difficult to attribute these parallels to a different explanation than to political conflicts rooted in the social structure - to cleavages. If attitudes were distributed randomly across the electorate, we would certainly not expect such large commonalities in the cultural and economic preferences of occupational classes across countries. Note also that individual-level analyses based on different data (and somewhat different class measures) report very similar spatial configurations of the electorate in Denmark (Harrits et al. 2009) and Switzerland (Oesch and Rennwald 2010).

In a last set of analyses, we estimate nested multinomial regressions on the determinants of choosing the radical right over the New Left. The objective is to determine the extent to which economic and cultural preferences account for the class differences in party choice. We examine four different models: Model 1 only includes the socio-demographic variables of gender, age, education, and class. Model 2 adds (and then removes) economic preferences, whereas Model 3 adds (and then removes) cultural preferences. Finally, Model 4 includes both economic and preferences together with socio-demographic determinants. Since we only dispose of all these measures in ESS round 4 (2008/2009), these analyses are run on a restricted sample and do not include Austria. The results are shown in Table A2.3 in the Appendix. While they provide us with a load of information on the determinants of voting behavior, we only discuss a few findings that seem particularly notable in the context of our study.

To begin with, socio-cultural professionals are everywhere systematically less prone to vote for the radical right as compared to the New Left than all other classes - except liberal and technical professionals - even accounting for differences in gender, age, and education (see Model 1). Holding preferences for economic redistribution clearly increases support for the New Left. Yet economic attitudes do not explain why socio-cultural professionals are more likely to favour the New Left over the radical right than other classes (see Model 2). 
In comparison, cultural attitudes seem to be much more relevant for understanding why some classes rally behind the New Left and others behind the radical right: the coefficients for cultural preferences are in all three countries larger than those for economic preferences, most notably so in Switzerland (see Model 3 ). Once we account for voters' cultural preferences, socio-cultural professionals and service workers no longer differ significantly in their party choice and also the differences between socio-cultural professionals and production workers decline substantially in the three countries under study.

Likewise, the effect of higher education on preferring the New Left over the radical right seems to be channeled through cultural preferences. Hence, once we control for differences in voters' cultural attitudes, the effect of education shrinks, and becomes even non-significant in Switzerland-yet obviously, education determines cultural preferences - and not the other way round. These results suggest that the effect of class and education on the new cultural conflict is mediated through citizens' cultural preferences: their attitudes towards immigration, supranational integration, and different lifestyles. But of course, our imperfectly measured attitudes do not entirely explain why highly educated socio-cultural professionals are particularly likely to vote for the New Left and less qualified production workers (as well as clerks) particularly likely to support the radical right.

\section{Conclusion}

This chapter has argued that the electoral competition between the New Left and the radical right is best understood as a cultural divide that is firmly anchored in different class constituencies. The argument has then been subjected to an empirical analysis based on individual-level data stemming from four rounds of the European Social Survey. In a nutshell, our major findings can be summed up as follows.

We clearly find that party choice is not distributed randomly across the electorates in Austria, Denmark, Norway, and Switzerland. On the contrary, the New Left attracts disproportionate support from socio-cultural professionals and presents a clear-cut middle-class profile, where younger voters with tertiary education are strongly over-represented, while workers, clerks, and small business owners are under-represented. The radical right's constituency presents the mirror image of the New Left. In all four countries, the radical right is most successful among production and service workers and receives least support from socio-cultural professionals. More generally, the radical right strongly depends on the votes of less educated men and older citizens. Radical right parties have thus turned into a new type of working-class party, as two-thirds of their voters in Austria, Denmark and Norway do not have middle-class status.

However, the analysis of voters' preferences suggests that the radical right's success within the working class is due not to economic but to cultural issues. The New Left and the radical right thus collide over a cultural conflict of identity and community - and not over questions of market regulation and state redistribution. Economically, the voters of the New Left hold similar preferences as those of the 
old left. Likewise, attitudes toward the economy do not differ significantly between the electorates of the radical right and the center right. Yet in cultural terms, the New Left is much more libertarian and the radical right much more authoritarian than the constituencies of the two established parties. The New Left and the radical right thus primarily compete along the cultural dimension of politics. However different these two camps are, both lose out - to the old left or the center right respectively - if distributive issues linked to the economy are more salient in electoral campaigns. Likewise, they both flourish where questions related to immigration and cultural diversity appear more relevant to voters (Bornschier 2010a: 6). In other words, the success of the New Left and the radical right depends on the salience of the cultural as compared to the economic conflict.

In short, our analysis thus suggests that a full-grown cleavage has emerged in the four small and affluent European countries under study, separating a libertarian-universalistic pole from an authoritarian-communitarian pole. The emergence of this new divide has been accompanied by a process of class realignment: the beneficiaries of educational expansion and occupational upgrading - notably socio-cultural professionals - have decisively contributed to the growth of the New Left. In contrast, those left out from the transition toward the knowledge and service society—notably production workers-were successfully recruited by the radical right.

\section{Appendix}

Table A2.1 Factor analysis for the economic preference axis

\begin{tabular}{lc}
\hline Variable & Factor 1 \\
\hline Standard of living for the unemployed, government responsibility & 0.74 \\
Standard of living for the old, government responsibility & 0.66 \\
Job for everyone, government responsibility & 0.59 \\
Government should reduce differences in income levels & 0.32 \\
Eigenvalue & 1.43 \\
Proportion variance explained by factor & 0.91 \\
\hline
\end{tabular}

Note

N (based on ESS 2008 for CH, DK, NO): 4,820.

Table A2.2 Factor analysis for the socio-cultural preference axis

\begin{tabular}{ll}
\hline Variable & Factor 1 \\
\hline Country's cultural life undermined or enriched by immigrants & 0.82 \\
Immigrants make country worse or better place to live & 0.82 \\
Gays and lesbians free to live life as they wish & 0.29 \\
European unification should go further or gone too far & 0.47 \\
Eigenvalue & 1.65 \\
Proportion variance explained by factor & 0.95 \\
\hline
\end{tabular}

Note

N (based on ESS 2004, 2006, 2008 for AT, CH, DK, NO): 18,366. 


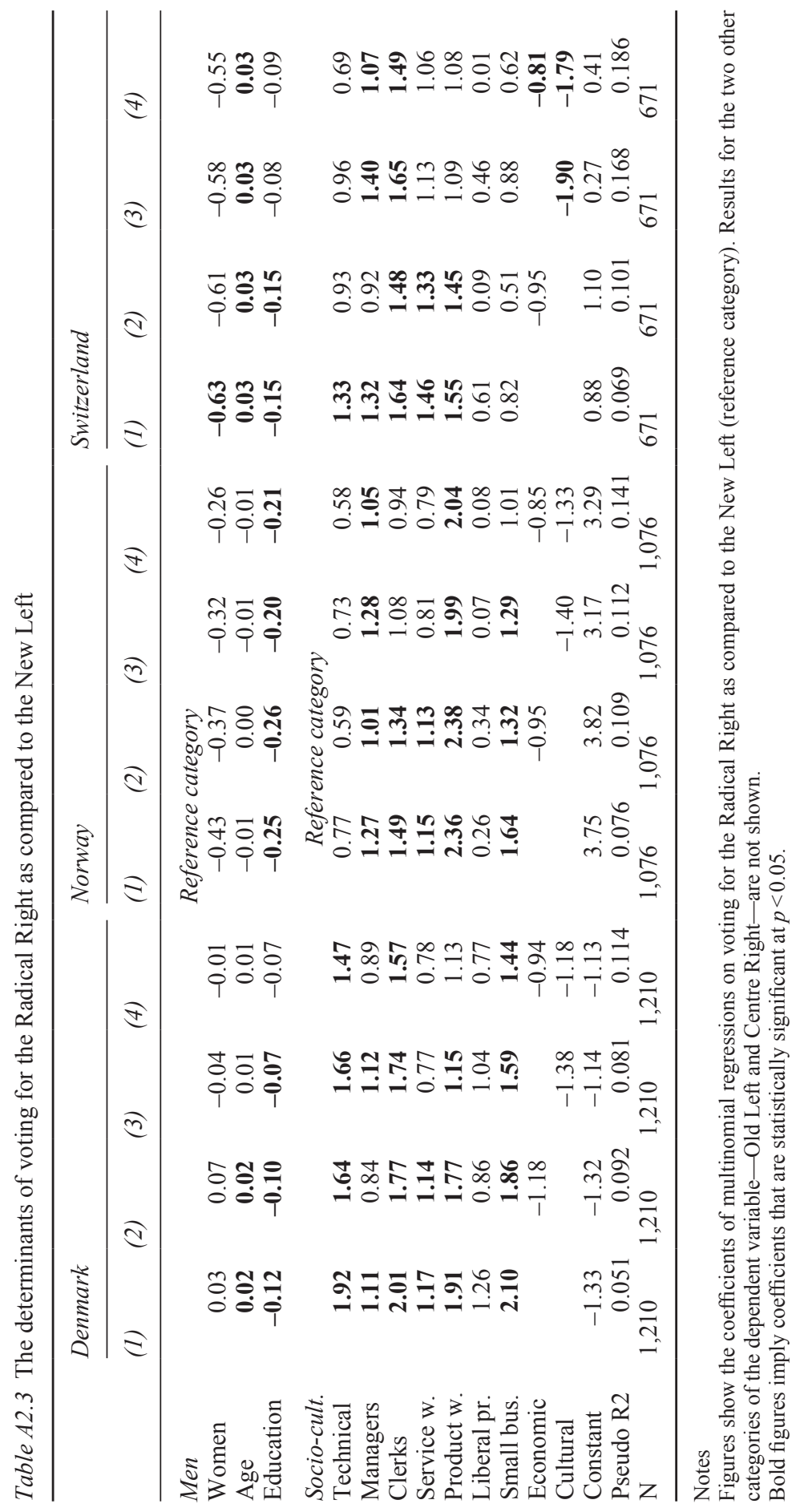




\section{Notes}

1 Note that Austria was only included in the first three survey rounds of the ESS, but not in ESS 2008/2009.

2 In order to allow for country differences in attitudes, our analyses below rely on factor analyses run separately by country. The attitudinal factors thus vary across countriesalthough surprisingly little. Since the questions used to construct the economic axis were only included in the ESS 2008/09 and thus not available for Austria, Austria's economic factor is based on three other questions, included in ESS2002/03: (1) government should reduce differences in income levels; (2) the less government intervenes in the economy, the better for the country; (3) employees need strong trade unions to protect work conditions.

3 The differences in electoral scores by gender are the following.

AT-New Left: 14 percent male, 18 percent female; radical right: 9 percent male, 5 percent female.

DK-New Left: 9 percent male, 13 percent female; radical right: 10 percent male, 7 percent female.

NO-New Left: 10 percent male, 18 percent female; radical right: 19 percent male, 13 percent female.

$\mathrm{CH}-\mathrm{New}$ Left: 9 percent male, 13 percent female; radical right: 30 percent male, 24 percent female.

4 The reference category is constituted of (associate) managers who vote for the center right. Significance levels correspond to $p<0.01$. Detailed results are available from the author. See also Table A2.3 in the Appendix, discussed below. 